\title{
E-GOVERNMENT IN THE ARABIAN GULF: A VISION TOWARD REALITY
}

\author{
George K. Kostopoulos \\ American University of Sharjah \\ kostopoulos@aus.ac.ae \\ $+971-6-515-2343$
}

\begin{abstract}
This paper presents a review of e-government initiatives in the Arabian Gulf, where extensive efforts are being made to capitalize on the cyber technologies in order to enhance the government to citizen service. The described cases are from Kuwait, Bahrain, Saudi Arabia, Qatar, the United Arab Emirates and Oman,. While the efforts vary in size and intensity, what appears to be common is the top level support the e-government initiatives are receiving, which offers them visibility and hopefully warrants their eventual success. The collective message delivered by the examined cases is that egovernment is becoming an integral part of the respective countries life with a byproduct being an increase in society's cyber-literacy.

The dual mission of the Dubai e-Government: "To ease the lives of people and business interacting with Government, and to contribute in establishing Dubai as a leading economic hub."
\end{abstract}

Sheikh Mohammed Bin Rashid Al Maktoum

\section{INTRODUCTION}

The Digital Age has revolutionized the marketplace, as well as the business-toconsumer and business-to-business relations. Now, the same force is transforming the model and protocol of interaction in extra-government and intra-government communications. The result of this transformation has been a new relationship in government-to-citizen, G2C, government-to-business, G2B, and most important in government-interagency, G2G, communications that is now Web based.

Considering that governments are mainly information producers, rather than information receivers, the Internet presents itself as the ideal intermediary becoming the $24 / 365$ passive call center for government-citizen interaction. Of course, nothing prevents it from being an interactive call center, as well, and this is where the ultimate challenge is.

Governments, around the world, and especially in the Gulf, responding to the society's continuously increasing cyber skills and wanting to capitalize on the Internet technologies, are funding numerous e-government projects aiming at enhancing their own productivity as well as that of their constituencies citizenry and business alike. Most projects are Web based, while others are high-tech telecommunications based.

e-Government in the Arabian Gulf: A Vision toward Reality - 1 


\begin{tabular}{|l|l|l|l|l||}
\multicolumn{2}{|c||}{$\begin{array}{c}\text { e-Government Portal } \\
\text { Objectives }\end{array}$} \\
\hline \multicolumn{2}{|c||}{ National } & & \multicolumn{3}{c||}{ International } \\
\hline $\begin{array}{l}\text { Documents } \\
\text { Depository \& } \\
\text { Information } \\
\text { Provider }\end{array}$ & $\begin{array}{l}\text { Transaction } \\
\text { Processing Center } \\
\text { with Live Interaction }\end{array}$ & & $\begin{array}{l}\text { Worldwide } \\
\text { Showcase of } \\
\text { Natural and } \\
\text { Cultural Wealth }\end{array}$ & $\begin{array}{l}\text { Permanent Promoter } \\
\text { of Political, Cultural } \\
\text { and Economic Aims }\end{array}$ \\
\hline \multicolumn{1}{|c|}{ Passive } & $24 / 7$ & & & Multilingual \\
\hline
\end{tabular}

Government administrations have recognized that an e-government portal - serving as the gateway to a National Web Depository - can simultaneously meet two important objectives, a national one and an international one.

The national objective is operational and dual. On one hand, it is to serve as a Depository of Documents and a one-stop information center - and on the other, to be a fully interactive service provider with call center capabilities functioning as the government's Transaction Processing System offering tactical automation.

The international objective is strategic and also dual. On one hand, it is to serve as a worldwide showcase, and on the other, a permanent promoter of that country's political, cultural and business aims.

In that respect, the Arabian Gulf States, rather lead in e-government initiatives and in services delivery.

Over the past two years, country after country, has initiated programs attempting to Web-enable the government-to-citizen and government-to-business interaction, also making it impersonal. This is significant governance transformation that will only have a positive impact on the path toward a transparent G2C relationship.

In the area of education, the information and communication
technology has become a cornerstone, and it is identified as "...the one and only international language..." [1]

As a result, similarly to the digital firm, more and more government agencies are moving employees from the front office to the back office of government service. Ultimately, the front office of government will be the Web, kiosks strategically located in areas of high foot traffic, as well as the SMS capabilities of the omni present mobile phones.

While in most countries around the globe e-government is treated as a necessary evil, in the Gulf, the $\mathrm{e}$ government vision has being placed on the top of the government priorities and with very impressive results; often serving as a G2C interaction showcase.

What is of special interest is that
many e-government projects are remarkable strategic innovations, rather than merely online replicas of offline government services. Yet, in most cases, e-payments over e-governments portals still remains a goal to be attained.

\section{OBSERVATIONS AND CONCERNS}

Despite the numerous advances in e-government, all across the Arabian Gulf - from Kuwait to Oman with exceptional vision displayed in Dubai there is a widespread fear that the digital divide will make the fruits of egovernment inaccessible to the majority of the society due to lack of cyber literacy.

Beyond the digital divide, an 
additional concern is also being expressed about another divide, namely the "... speed divide..." [2], where the haves will have broadband access to the Internet $(10 \mathrm{Mb} / \mathrm{s})$, while the have-nots will have a mere telephone modem connection $(56 \mathrm{~Kb} / \mathrm{s})$. Consequently, the accessed content will be, respectively, rich and poor, at least when it comes to multimedia. "Unless these infrastructure deficiencies are eliminated, the surge in Internet users ... will definitely cause problems." [3]. The general fear is that the Internet access facilitators - the backbone access providers and the Internet service providers - in order to maximize their return on investment will not meet the access demand. As a result, the growth rate in Internet utilization will decline.

Another concern is the way egovernment projects are being reviewed and funded. Such projects in the Gulf appear to be "...budget-based projects rather than being in project-based budgets..." [4], and "to move from vision to reality, such a transformation needs a committed leadership, a sound strategy, a seamless cross-coordination between various agencies and organizations as well as the know-how." [3].

Despite the various concerns, there is a very positive outlook toward egovernment in the Gulf, with several believing that the e-government initiatives not only will show that the "... government is too rigid..." [5], but will also serve as an agent for change. As a result, there is a high expectation for government processes streamlining, modernization and reforms.

The implementation of the egovernment projects requires skilled human resources that not available within the governments themselves. Consequently, consultants and local partners are been contracted for assistance and most important for technology transfer.

\section{SELECTED e-GOVERNMENT CASES}

Kuwait has been very active in egovernment with a variety of projects and activities, such as,

a. The development of a Judiciary Information Database, with the support of the United Nations Development Programme [6].

b. Organization of Kuwait's first eGovernment Conference sponsored by the Al--Faris Group "...to create awareness among business and IT executive ... to deploy latest web technologies...". [7].

c. The sponsorship of a large eGovernment conference in Kuwait, in April 22-24, 2002, with the support of Microsoft [8].

d. The participation of a wide range of consultants including the AlBared Group, which "... has committed itself to finding a workable solution for the implementation of an e-government infrastructure in the State of Kuwait. [9].

e. "In collaboration with the Kuwaiti government, FAPCO is in the advanced stages of setting up the infrastructure of EGovernment services and solutions for the State of Kuwait". This project can be best defined as the first electronic public library in the Gulf, and will include more than 800 pages translated into six different languages. The website is an official source for all sort of information, public data, geography, history, photos, and references about the State of Kuwait. [10].

Kuwait having realized the need for a comprehensive and strategic plan for addressing the issue of developing and maintaining an e-government service "...created the Secretariat for the Central Technical System..." within the Ministry of Planning. In Spring of 2002, Kuwait launched an international tender for proposals - based on detailed eGovernment Project "Product Specifications" - seeking responses from 
e-government experienced companies [11].

Bahrain has been first to introduce evoting. During February 14-15, 2001, the 200,000 Bahraini voters participated in referendum where they had the opportunity to express their position in a variety of national issues. As a voter's registration identification card, their CPR card was used (Central Population Registration Card) was used. The card has a significant amount of information on it that is optically encoded in a twodimensional bar-code scheme. "The 2D barcodes on the card contain securely encrypted data to guarantee consistency of the personal information and the eligibility of the voter in a matter of seconds." [12]. The scheme is based on a technology developed by Symbol Technologies, Inc. [13].

Saudi Arabia makes extensive use of the Web as a bulletin board, with the most visible e-government effort being the creation of a special website serving the informational needs of the Umra pilgrims. Initially designed as an extranet for use between the Saudi Ministry of Hajj and the travel agent and tour operators, it is eventually growing into a major portal for all related services, such as visas, and travel and accommodations reservations. The site's mission is "... to fully exploit the emerged driving force of the Internet technology ..." for the logistical support of the Umra pilgrimage [14].

Qatar has launched a thirty month egovernment effort designed to e-enable all government. The starting point is a pilot program addressing the renewal of the resident permits [15]. The project was implemented within two months, opening the way for similar initiatives in other government operations, such as passports and permits. The Qatari vision goes beyond the Web replication of the $\mathrm{G} 2 \mathrm{C}$ and the $\mathrm{G} 2 \mathrm{~B}$ operations aiming at including the Web delivery of "... e-knowledge ...".

The Qatari government already has a large database with a single view of the individual. This is, an individual's file that contains all aspects of the G2C relationship. The objective is to extend access to such files to all government agencies, and to have all government agencies make relevant data contributions to that master database.

The vision includes the use of additional front end delivery channels, beyond the Internet, such as kiosks and SMS via mobile phones. While there is budget and determination to realize numerous e-government projects, "There is a curve involved ... (and) more experience ... (to be gained before) ... rolling these systems out." [16].

United Arab Emirates, especially the Emirate of Dubai, stand as the undisputed leader in e-government, where the ". . . the crown prince has launched his own web site, http://www.sheikhmohammed.co.ae, as a platform for Internet technology and digital medium for facilitating contact between the leader and his people.". In Dubai, among the numerous initiatives, one of the most ingenious ones is the use of the Internet for the completion of tourist visa applications, where the application when printed displays a computer readable two-dimensional bar code that represents the entered information. As a result the associated staff was reduced to half, while the application processing time decreased from days to hours. "In the high season this can run at over 3,000 visas per day" [17].

In Dubai, a program has been implemented where citizens can subscribe with the police department and receive "... up-to-the-minute traffic reports ..." and other information via SMS (Short Message Services). Another high tech service is the department's WAP 
site. Here, citizens can scroll through it, viewed on their cell phone, and find information needed on the road, such as the nearest police station. The department also has in its website link to the stolen cars database, kiosks located in shopping malls where motorists may find out if they have any outstanding speeding tickets entered by the radar cameras [18].

Dubai has also introduced an ewallet called $m$-Dirham, after the name of its currency. In the scheme citizen deposit money in a third party financial institution from where they may transfer to pay permit fees and the like [19]. In an effort to integrate the woman in the mainstream of employment, several IT training programs are being implemented in the Arabian Gulf, including one in Dubai in cooperation with UNESCO, addressed to women. Indeed, "Technology presents immense opportunities for women to make productive use of their talents without breaking the conventions of society." [20].

The above is only a sample of the long list of currently operational egovernment projects undertaken by the Dubai police department. It is apparent that the Dubai e-government effort is one of the most citizen-centric serving as an example not only in the Arabian Gulf region but worldwide.

Oman is currently implementing a holistic approach to the $e$ - moving "... towards (an) e-Oman (strategy), which consists of e-government, e-commerce, elearning and other e-services,...". A government taskforce, formed for that purpose, after having realized the breadth and the depth of the needed technological and change- managerial skills, has sought the services of international consulting houses to lead them through the maze of e-gov design. The taskforce is studying egovernment implementation applied elsewhere in an effort to learn from the mistakes of others than from their own. The taskforce wants to "... remove the stupid rules and regulations and put the whole process on the Internet." and serve as the e-Oman "godfather". [21].

Addressing the issue of cyber illiteracy and digital divide, Oman has initiated numerous programs on computer and Internet literacy, especially for the Omani women, hoping to at least partially bridge the gap.

\section{CONCLUSION}

In researching e-government in the Arabian Gulf, the following two issues appeared to be:

1. Change Management. How the old bureaucracies will give place to the etechnocracies? How the old rules and regulations that provided importance and job security to the mandarins of the ministries will be declared irrelevant in today's globalization?

2. Cadre Creation. The realization of any e-government requires a hard core of techies to design and develop the e-government and an army of IT savvy civil service to use the e-government machinery. Where will the former come from and how will the latter acquire that IT savvy?

3. Public's Cyber Literacy. When a government builds a superhighway, soon after its completion the motorists flood it; it is because they have a car and know how to drive. On the other hand, when a government builds its e-gov superhighway will the citizens use it?

In closing, in the Arabian Gulf, the e-government vision is slowly, but surely, becoming a reality creating a trilateral win-win-win situation for all - the government, the business and the citizen. Giving the credit where it 
belongs, it must be said that the Dubai e-government is the asymptote model all others try to reach. But how can an asymptote be reached when it continuously attains higher and higher levels?

\section{REFERENCES}

[1] Al-Khalifa, Hessa, Keynote address, Eighth GCC e-Government, Internet \& Telecommunications Forum, May 28-29, 2002, Dubai, UAE.

[2] Al-Shuraida, Ali, Where the GCC are Heading with the e-Government Projects?, Eighth GCC e-government, Internet \& Telecommunications Forum, May 28-29, 2002, Dubai, UAE.

[3] E-Initiatives in the GCC region http://www.meib.org/articles/0012_me2.htm [4] Gottipati, Madan, Managing eGovernment Portals, Eighth GCC egovernment, Internet \& Telecommunications Forum, May 28-29, 2002, Dubai, UAE.

[5] Moores, Simon, e-Government Portals, Eighth GCC e-government, Internet \& Telecommunications Forum, May 28-29, 2002, Dubai, UAE.

[6] e-Government: Considerations for Arab States, United Nations Development Programme

http://www.surf-as.org/Papers/e-govenglish.pdf

[7] Al-Faris is sponsoring the Kuwait First e-Government Conference

http://my.al-

faris.com/corp/press/presscenter.jhtml

?passval $=2503$ egov

[8] Microsoft sponsors Kuwait's largest eGovernment conference

http://www.microsoft.com/middleeast/pre ss

[9] E-government, Al-Bader Group, http://www.al-bader.com/newprojects.htm

[10] FAPCO - Kuwait e-Gov Project http://www.fapco.net/body_government.h tml

[11] Trade Leads Kuwait e-Government Project.
http://exportit.ita.doc.gov/ocbe/TradeLe a.nsf/3bd0821046786c8d8525651a0064 0818/05717e23a369991485256b870072 a454! OpenDocument

[12] Bahrainis Become Middle East's First e-Voters.

http://www.symbol.com/news/pressreleas es/pr_releases_inter_bahrain.html

[13] Symbol Technologies, Inc. 2D Barcode Readers

http://www.symbol.com/products/barcode _scanners/barcode_scanners.html

[14] Umra Performance http://www.babalumra.com/english/inde x.html

[15] Qatar goes live with first-phase egovernment project

http://www.itp.net/news/9681422167834 7.htm

[16] Qatar builds e-government portal http://www.itp.net/features/97556902273 780.htm

[17] Dubai Naturalisation and Residency Administration Implements EGovernment with Symbol Technology http://www.symbol.com/news/pressreleas es/pr_releases_inter_dubai.html

[18] Dubai Police m-enables its officers with SMS and WAP services

http://www.ducont.com/press_release/AC N_2000.htm

[19] 'Mobile Dirham' service launched http://www.gulf-news.com/Articles/

News.asp? ArticleID $=29361$

[20] Dubai e-Government drives IT awareness among local females http://www.itp.net/news/1022131564698 82.htm

[21] Oman begins work on e-Sultanate strategy

http://www.itp.net/features/10205827324 6315.htm

\section{BIOGRAPHY}

Dr. George Kostopoulos is a Professor of Information Systems with the School of Business Management at the American University of Sharjah, AUS, in the United Arab Emirates. He holds degrees from the Arizona State University, Ph.D. and M.S. in Electrical and Computer 
Engineering, the California State Polytechnic University, M.S. in Economics, and the Pacific States University, B.S. in Electronics Engineering.

After his first graduation in 1962 and until 1975, he served in the defense electronics industry in various capacities holding research and development positions that progressively ranged from engineer to principal scientist. His engineering activities were digital systems design in the areas of phased array antennas, missile, torpedo guidance, radars and sonars systems.

His academic career started in 1974 when he joined the California State Polytechnic University as an associate professor of electrical and computer engineering. Since then, he has been a faculty member in numerous universities around the world including the University of Petroleum and Minerals in Dhahran, Saudi Arabia, the Algerian National Institute of Electrical Engineering (INELEC), the Florida Institute of Technology, the Florida Atlantic University, the Boston University, the University of Heidelberg, the University of LaVerne (California) Athens campus, the Greek National University of Ioannina, the Texas A\&M International University, and the Instituto Tamaulipeco de Investigacion Educativa y Desarrollo de la Docencia of Victoria, Mexico.

Dr. Kostopoulos' professional interests are in the use of the Internet for education, commerce and government. 